\title{
Measuring sodium alginate content of brown algae species padina sp. as the basic matter for making dental impression material (irreversible hydrocolloid impression material)
}

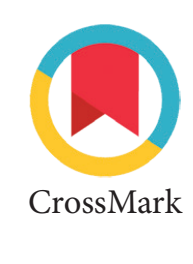

\author{
Nurlindah Hamrun, ${ }^{*}$ Suci A. Rachman
}

\section{Abstract}

Objective: Our study aimed to identify how much sodium alginate is produced from padina sp. extract, which as is the basic matter of irreversible hydrocolloid.

Material and Methods: The design of this study is an experimental design that used a one-shot case study method. In early stages of research, extraction of alginate in the form of sodium alginate was carried out. After that, the extracted material was weighed and the measurements were recorded as weight in milligrams $(\mathrm{mg})$. Then, the extracted material was compared with standard sodium alginate to observe the similarity of molecules by using FTIR (Fourier Transform Infrared) device.
Results: Data were analyzed using mean differences. The padina extracted had a quantity of $12.86 \mathrm{~g}$ of sodium alginate content (28.4\%) and combined with the cleaning algae the total weight was $45 \mathrm{~g}$. The FTIR test showed that sodium alginate extracted was similar to the standard sodium alginate in regards to contents of hydroxyl, carboxylic acid and ether which are standard constituents of sodium alginate. Conclusion: From both infrared spectrum patterns, the difference between the components of the two types of sodium alginate, one standard and another extracted from the algae, was not significant. Extracted sodium alginate padina sp. is similar to the standard sodium alginate in all respects, with a sodium alginate content of $12.86 \mathrm{~g}$.

Keywords: Alginate, Hydrocolloid irreversible, Brown algae padina sp.

Cite this Article: Hamrun N, Rachman SA. 2016. Measuring sodium alginate content of brown algae species padina sp. as the basic matter for making dental impression material (irreversible hydrocolloid impression material). Journal of Dentomaxillofacial Science 1(2): 122-126. D0I:10.15562/jdmfs.v1i2.11

Department of Oral Biology, Faculty of Dentistry, Hasanuddin University, Makassar, Indonesia
"Correspondence to: Nurlindah Hamrun, Department of Oral Biology, Faculty of Dentistry, Hasanuddin University, Makassar, Indonesia

lindahamrun@gmail.com

Received:09 March 2016

Revised: 25 April 2016 Accepted: 26 April 2016 Available Online: 30 April 2016

\section{Introduction}

An important step in orthodontic treatment procedure and prostheses manufacture is modeling. This is because the model is used by dentists to design and construct prostheses as well as orthodontic instruments and the model thus designed must accurately represent the structure of the mouth. One of the printed materials widely used in the dentistry field is the alginate printed material (irreversible hydrocolloid). ${ }^{1}$

Alginate is a polysaccharide extracted from brown algae. Basically, all brown algae species contain alginate, but only a few species were extracted for the alginate production commercially. Most of alginate materials necessary in Indonesia are still procured by importing because there is no alginofit cultivation yet (algae producer of alginate), this in turn has made printed materials relatively expensive in Indonesia and led to high cost of dental health care. ${ }^{2,3}$

In Indonesia seaweed is used only as a food item and thus its use is mainly restricted to domestic consumption. It is not fully utilized for industry, especially as the printed material in dentistry. ${ }^{4}$ Indonesia is an archipelagic country with abundant marine resources. The brown algae Padina sp., especially in the Puntondo-Punaga waters, South Sulawesi province, is available abundantly, but it has not been cultivated by the local community given the industry's lack of knowledge about its special properties. Thus, the algae grows in the wilderness and goes unutilized.

This study aimed to identify how many sodium alginates are produced from brown seaweed extraction (panida sp.) that can be used as a raw material of alginate printed material (irreversible hydrocolloid impression material).

\section{Material and Methods}

The sample used in this research is a brown algae species, padina sp., taken from Punaga and Puntondo coast in Takalar, South Sulawesi, Indonesia. A quantity of $45 \mathrm{~g}$ of dry brown algae was extracted to obtain sodium alginate from it. Then the sodium alginate derived from the 
extraction process was compared to standard sodium alginate using FTIR (Fourier Transform Infrared).

Overall, the following activities were carried out during the study: sodium alginate extraction, FTIR testing and analysis of infrared spectra.

\section{Sodium alginate extraction}

A quantity of $45 \mathrm{~g}$ of dried brown algae was soaked in $\mathrm{HCl}$ solution for 1 hour and washed with distilled water 3 times and $\mathrm{Na}_{2} \mathrm{CO}_{3}$ at $4 \%$ was added to the sample. Thereafter, the sample was heated at $60^{\circ} \mathrm{C}$ for 2 hours and was stirred frequently, until it become a paste. This mixture is diluted with distilled water, kept still for about 30 minutes, and then filtered. Filtering results: $\mathrm{HCl}$ $5 \%$ was added to the filtrate until the $\mathrm{pH}$ reached 2-3 and the sample was kept as is for 5 hours. $\mathrm{NaOCl} 1 \%$ was added to the sample to form an even mix. $\mathrm{NaOH}$ at $10 \%$ was added to the sample until its $\mathrm{pH}$ reached 9 and the sample was allowed to settle for 5 hours. The sample was centrifuged for 5 minutes to form a sediment and liquid. Isopropanol 95\% was added to the sediment and was kept frozen for 12 hours. Then the sediment was freeze-dried until it became a powder and then pureed using a blender. After that, sodium alginate obtained from the extract of padina sp. was weighed with analytical scales.

\section{FTIR (Fourier Transform Infrared) testing}

Sodium alginate was crushed into very fine powder and screened again and then the powder was mixed with $\mathrm{KBr}$ powder. Then the mix was put through a mini hand-press tool to form into a thin disc/tablet. The disk was laid on a sample place in FTIR for

Table 1 Average measurements of sodium alginate from brown algae Padina sp.

\begin{tabular}{lcc}
\hline Variable & $\begin{array}{c}\text { The content mean of } \\
\text { sodium alginate }(\mathbf{g})\end{array}$ & Percentage \\
\hline Sodium alginate & 12.86 & 28.4 \\
$\begin{array}{l}\text { Salt, chlorophyll, carotene, } \\
\text { violaxanthin, and fucoxanthin }\end{array}$ & 32.14 & 71.6 \\
Total & 45 & 100 \\
\hline
\end{tabular}

Table 2 Physical characteristics of sodium alginate standard and sodium alginate extracted from Padina sp.

\begin{tabular}{lcc}
\hline Variable & Sodium alginate standard & $\begin{array}{c}\text { Sodium alginate extracted } \\
\text { from Padina sp. }\end{array}$ \\
\hline Color & tawny & blackish brown \\
Smell & not fishy & Fishy \\
\hline
\end{tabular}

analysis. Spectra data were displayed on a computer connected to the tool.

\section{Interpretation of infrared spectra}

Analysis of the infrared spectra was focused on determining the presence or absence of several major functional groups, such as $\mathrm{C}=\mathrm{O}, \mathrm{OH}$, $\mathrm{N}-\mathrm{NH}, \mathrm{CO}, \mathrm{C}=\mathrm{C}, \mathrm{C} \equiv \mathrm{C}, \mathrm{C} \equiv \mathrm{N}$ and $\mathrm{NO}_{2}$. Note the presence of the $\mathrm{C}=\mathrm{O}$ group. Group $\mathrm{C}=\mathrm{O}$ was identified in the $1820-1600 \mathrm{~cm}^{-1}$ area. This is usually the strongest peak with medium width in the spectrum. If the group $\mathrm{C}=\mathrm{O}$ exists, it indicates the presence of - $\mathrm{OH}$ (absorption gets close to $3.400-2.400 \mathrm{~cm}^{-1}$ ), $-\mathrm{NH}$ (medium absorption near $3.500 \mathrm{~cm}^{-1}$ ), CO (strong absorption near 1.300-1.000 $\mathrm{cm}^{-1}$ ) and $\mathrm{CH}$ aldehyde (two weak absorption spots near 2.850 and $2.750 \mathrm{~cm}^{-1}$, which is on the right uptake $\mathrm{CH}$ ).

If the group $\mathrm{C}=\mathrm{O}$ doesn't exist, it means the presence of test $\mathrm{OH}$ group (absorption extends until 3.300 near $3.600 \mathrm{~cm}^{-1}$ ). Next variable is the $\mathrm{CO}$ absorption, which occurs near $1.300-1.000 \mathrm{~cm}^{-1}$, in addition to test $\mathrm{NH}$ (medium absorption near 3.500 $\mathrm{cm}^{-1}$ ) and test $\mathrm{CO}$ uptake (no $\mathrm{OH}$ absorption) near $1.300-1.000 \mathrm{~cm}^{-1}$.

The next step is considering the existence of a double bond and/or aromatic ring. $\mathrm{C}=\mathrm{C}$ has a weak absorption near $1.650 \mathrm{~cm}^{-1}$. High medium-strong absorption between 1.650 and $1.450 \mathrm{~cm}^{-1}$ often indicates the presence of an aromatic ring, proving there is a possibility of absorption in the $\mathrm{CH}$ area. Aromatic bond and vinyl $\mathrm{CH}$ were found on the left $3.000 \mathrm{~cm}^{-1}$, while aliphatic $\mathrm{CH}$ occurred on the right-side area.

Then, we noticed the presence of a triple bond. $\mathrm{C} \equiv \mathrm{N}$ has a medium and sharp absorption near $2.250 \mathrm{~cm}^{-1}$. C $\equiv \mathrm{C}$ has a weak but sharp absorption near $2150 \mathrm{~cm}^{-1}$. Test $\mathrm{CH}$ asetilenik occurs near $3.300 \mathrm{~cm}^{-1}$.

\section{Results}

Research conducted in the Biofarmaka Laboratory in the Center for Research and Laboratory of Organic Chemistry Faculty of Mathematics and Natural Sciences Hasanuddin University, indicated that the extraction of sodium alginate from brown algae padina sp. That was obtained in powder form had a weight of $12.86 \mathrm{~g}$ or $28.4 \%$ of the total dry weight of the algae used at $45 \mathrm{~g}$.

In FTIR spectrum analysis of standard sodium alginate, absorption broadened at wave number $3446.79 \mathrm{~cm}^{-1}$ indicating a hydrogen bond with the hydroxyl group $(\mathrm{OH})$. Absorption at $2924.09 \mathrm{~cm}^{-1}$ 
Table 3 Comparison of standard FTIR spectrum of sodium alginate and sodium alginate extraction Padina sp.

\begin{tabular}{ccccc}
\hline $\begin{array}{c}\text { Sodium alginate } \\
\text { extraction results } \\
\text { Padina sp. }\end{array}$ & $\begin{array}{c}\text { Sodium alginate } \\
\text { standard }\end{array}$ & $\begin{array}{c}\text { Interpretation of } \\
\text { functional groups }\end{array}$ & $\begin{array}{c}\text { Reference } \\
\text { wave number } \\
\left(\mathbf{c m}^{-1)}\right.\end{array}$ \\
\hline 3423.65 & 3446.79 & Hydroxyl group $(\mathrm{OH})$ & $3500-3200$ \\
2922.16 & 2924.09 & Aliphatic $(\mathrm{CH})$ & $3000-2850$ \\
1627.92 & 1643.35 & Carbonyl $(\mathrm{C}=\mathrm{O})$ & $1820-1600$ \\
1419.61 & 1419.61 & C = C aromatic & $1475-1450$ \\
1031.92 & 1122.57 & Carboxyl group (CO) & $1300-1000$ \\
\hline
\end{tabular}

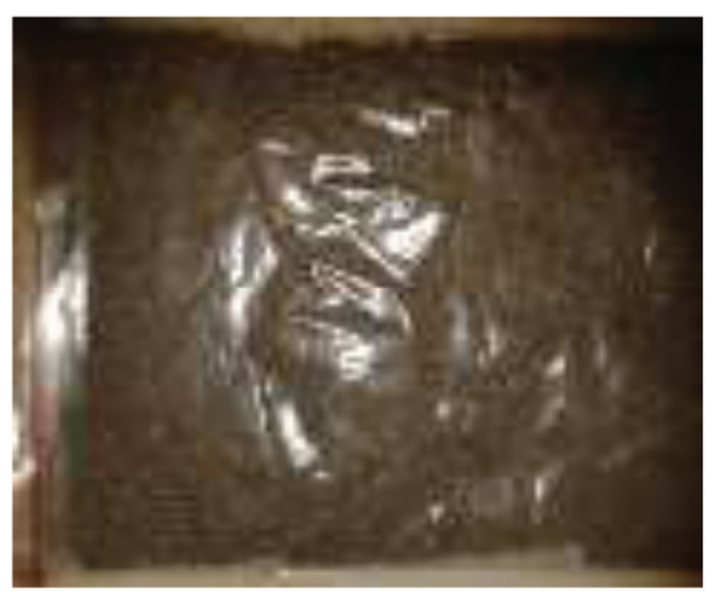

Figure 1 Results of sodium alginate extraction from Padina sp.

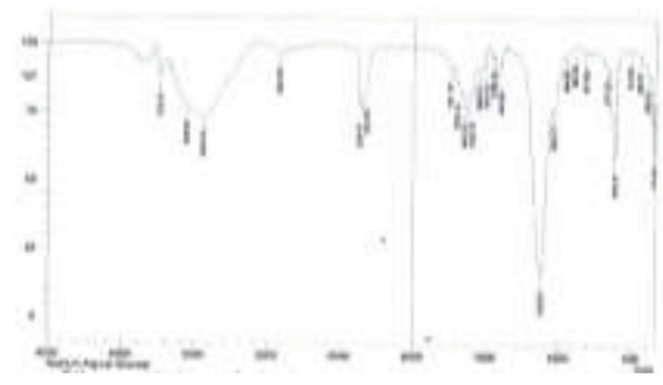

Wave number $\left(\mathrm{cm}^{-1)}\right.$

Figure 2 Infrared spectra of standard sodium alginate

showed aliphatic $\mathrm{CH}$. Absorption at $1643.35 \mathrm{~cm}^{-1}$ indicated carbonyl group $(\mathrm{C}=\mathrm{O})$. Absorption at $1419.61 \mathrm{~cm}^{-1}$ was $\mathrm{C}=\mathrm{C}$ aromatic. Absorption at $1122.57 \mathrm{~cm}^{-1}$ indicated carboxyl group (CO). FTIR test results can be seen in figures 2 and 3 .

The FTIR spectrum of sodium alginate extracted from brown algae padina sp. showed that absorption broadened at $3423.65 \mathrm{~cm}^{-1}$ indicating a hydroxyl group (OH). Absorption at 2922.16 $\mathrm{cm}^{-1}$ showed aliphatic $\mathrm{CH}$ bonds. Absorption at $1627.92 \mathrm{~cm}^{-1}$ indicated the presence of a carbonyl

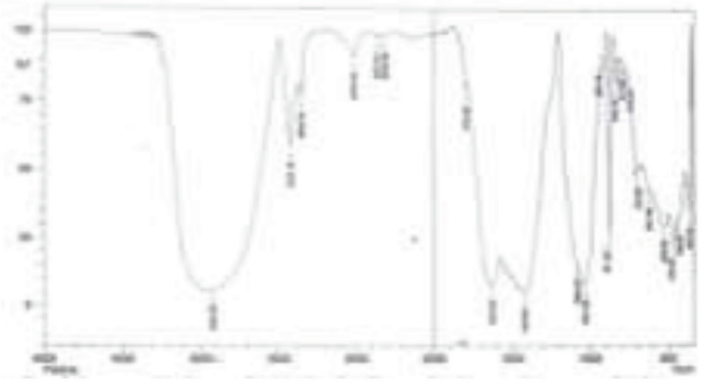

Wave number $(\mathrm{cm}-1)$

Figure 3 Infrared spectra of sodium alginate extracted from Padina Sp.

group $(\mathrm{C}=\mathrm{O})$ and absorption at $1031.92 \mathrm{~cm}^{-1}$ indicated the carboxyl group (CO). Absorption peaks $900-890 \mathrm{~cm}^{-1}$ showed a typical strip of guluronic fingerprints, while the peaks at $850-810 \mathrm{~cm}^{-1}$ showed a typical fingerprint mannuronat area. The typical guluronic and mannuronat area is a marker providing the evidence for the presence of sodium alginate. The presence of hydroxyl, carboxylic and ethers which constitute sodium alginate showed that the properties of sodium alginate extract are same as the standard sodium alginate. The second pattern of infrared spectra showed a significant difference.

In the infrared spectra pattern of samples, we found there is a slightly different absorption peaks with the standard sodium alginate. This shows there are still other functional groups participating in the process of purification of the filtered sodium alginate samples.

\section{Discussion}

Levels of sodium alginate are influenced by several factors, such as brown algae species, site location and extracting method. Growing location includes water conditions, $\mathrm{pH}$, salinity, light, water depth and nutrients. Another factor that may affect the levels of sodium alginate produced in this research is the sample quality. Morphologically, talus forms are different for each type of brown algae. This talus shape can also influence the levels of sodium alginate produced. Different methods in extracting influence the quality of the extraction, because the extraction process requires a particular treatment, such as the usage of reagents with certain concentration, amount of reagents, $\mathrm{pH}$, heating temperature and drying, bleacher types and the type of precipitator solution used. ${ }^{2,9}$

At the initial process of the extraction in this research, algae was soaked in an acid solution $(\mathrm{HCl})$ to dissolve the salts, mannitol and dyes. In 
addition, this was also done to dissolve impurities so that algae can be clean, while soaking the algae in an alkaline solution aimed to neutralize acid conditions. ${ }^{10}$ In the cell walls of brown algae, there is water-insoluble cellulose. Strong acids can hydrolyze cellulose, therefore, soaking the algae in a solution of $\mathrm{HCl}$ can break down the cell walls and cellulose. This will facilitate the subsequent extraction process. ${ }^{11}$

The process of separating alginate acid from cellulose was conducted under alkaline conditions by using $\mathrm{Na}_{2} \mathrm{CO}_{3}$. As a basic salt $\mathrm{Na}_{2} \mathrm{CO}_{3}$ dissolves much alginate but if the $\mathrm{Na}_{2} \mathrm{CO}_{3}$ concentration is too high, alginate polymer will be degraded. The concentration of $\mathrm{Na}_{2} \mathrm{CO}_{3}$ at 3-5\% can reduce the sedimentation and viscosity of alginate extract. The reason is alginate acid is degraded by an alkaline solution by cutting the polymer chains into oligosaccharides and degraded further into 4 acid deoxy 5 keturonat. The addition of $\mathrm{Na}_{2} \mathrm{CO}_{3}$ also serves to break down pectin in the cell walls of the brown algae. Pectin serves as an adhesive between one cell wall and another and these compounds are unstable in alkaline conditions. In the extracting process, the algae is heated at $60^{\circ} \mathrm{C}$ and the heating is aimed to speed up the extracting process and get more alginate extract. ${ }^{12,13}$

The outcome of this process was an alginate which is likely still mixed with other substances or has residual dirt that has not been removed. Therefore, filtering was done to produce residue and filtrate. Furthermore, the obtained filtrate is passed the bleaching process or discoloration by adding $\mathrm{NaOCl}$ so that sodium alginate extract has a clearer color. Bleaching occurs due to the dissolution of the phenol compounds contained in alginate polymer. The filtrate then goes through bleaching process and $\mathrm{HCl}$ is added to the filtrate so that the acid can precipitate alginate. Further filtering was done to separate the alginate acid sediment out of the solution. To get the alginate in the form of sodium alginate, we added the $\mathrm{NaOH}$ or $\mathrm{Na}_{2} \mathrm{CO}_{3}$ solution The purpose of changing alginate to sodium alginate is to get alginate in a stable form. After that, isopropanol was used to extract sodium alginate from sodium alginate solution. Then, alginate was freeze-dried using a freeze dryer and pulverized to obtain fine powder of sodium alginate. Sodium alginates derived from brown algae have a darker color, which is possibly due to insoluble phenol compounds in bleaching or discoloration process. ${ }^{14,15}$

The molecular weight of sodium alginate was $28.4 \%$ of the weight of dry algae, which means the weight is less than the weight of sodium alginate as reported in the literature, that is, it has about $40 \%$ of the total weight of dry algae. The results from previous research conducted by Rasyid $^{2}$ using algae species sargassum (sargassum crassifolium, polycystum sargassum and sargassum plagyophyllum) collected from the South Sulawesi waters showed that sodium alginate content was as much $23.86-30.1 \%$, which means the results of the present study do not differ greatly.

\section{Conclusion}

Based on the results, it can be concluded that the levels of sodium alginate extracted from brown algae padina sp. is $12.86 \mathrm{~g}$ or $28.4 \%$ of the total weight of the dry algae at $45 \mathrm{~g}$. Sodium alginate extracting process is similar to sodium alginate standard process; the FTIR test indicated the presence of hydroxyl, carboxylic and ethers in sodium alginate extracted from padina sp., which are constituents of standard sodium alginate.

\section{Conflict of Interest}

The authors report no conflict of interest.

\section{References}

1. Anusavice KJ. Phillip's Buku ajar ilmu bahan kedokteran gigi. 10th ed. In Budiman JA, Purwoko S, editors. Jakarta: EGC; 2004. p. 93-109.

2. Rasyid A. Karakteristik natrium alginat hasil ekstraksi sargassum polycystum. Seminar Riptek Kelautan Nasional. Jakarta: 2003. p. 1-4.

3. Rasyid A. Algae coklat (phaeophyta) sebagai sumber alginat. Oseana 2003; 33-38.

4. Suparmi, Sahri A. Mengenal potensi rumput laut: kajian pemanfaatan sumber daya rumput laut dari aspek industri dan kesehatan. Sultan Agung; 2009. p. 95-111.

5. Widiyanti P, Siswanto. Physical characteristic of brown algae (phaeophyta) from Madura strait as irreversible hydrocolloid impression material. Dent J 2012;45: 177-179.

6. Tisnado RR, Crmona GH, Gutierrez FL, et al. Sodium and potassium alginates extracted from macrocystic pyrifera algae for use in dental impression material. Ciencas Marinas 2004;30: 188-199.

7. Parthiban C, Parameswari K, Saranya C, et al. Production of sodium alginate from selected seaweeds and their physiochemical and biochemical properties. Asian Pacific Journal of Tropical Biomedicine 2012: 1-4.

8. Noerdin A, Irawan B, Febriani M. Pemanfaatan pati ubi kayu (manihot utilisima) sebagai campuran bahan cetak gigi alginate. Makara Kesehatan; 2003. p. 71-74.

9. Rasyid A. Perbandingan kualitas natrium alginat beberapa jenis alga coklat. Pusat Penelitian Oseanografi LIPI: Oseanologi dan Limnologi Indonesia 2009;35: 57-64.

10. Fengel W. Kayu: kimia, ultrastruktur, rekasi-reaksi. In Sastoamidjojo. Yogyakarta: Gadjah Mada University Press; 1995. 
11. Chou HN, Chiang YM. Studies on algin from brown algae of Taiwan1976. In Daam Yunizal, editor. Teknologi ekstraksi alginat. Jakarta: Pusat Riset Pengolahan Produk dan Sosial Ekonomi Kelautan dan Perikanan; 2004.

12. Winarno FG. Teknologi pengolahan rumput laut. Jakarta: Pustaka Sinar Harapan; 1996.

13. Yani M. Modifikasi dan optimasi proses esktraksi dalam rancang bangun proses tepung alginate dari jenis turbi-naria ornata. Skripsi. Fakultas Teknologi Pertanian. IPB; 1988
14. Yuniza. Teknologi ekstraksi alginat. Jakarta: Pusat Riset Pengolahan Produk dan Sosial Ekonomi Kelautan dan Perikanan; 2004.

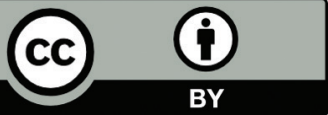

This work is licensed under a Creative Commons Attribution 